\title{
Nam giới ở nông thôn Việt Nam dễ vay tiền hơn và vay được nhiều tiền hơn
}

\author{
Nguyễn Việt Hà \\ Viet Panorama Media Monitoring
}

$16-5-2018$

(VietPan) — Nhân sự kiện một công ty cho vay tài chính gần đây vừa vướng vào vụ lùm xùm với các khách hàng ở nông thôn, SciComm xem được giới thiệu một nghiên mới đăng trong năm 2018 của nhóm tác giả Trần Thị Kiêu Vân (China Agricultural University) cùng Phạm Quang Trung (CIEM) và Trần Thùy Dương (Hanoi University) và 2 tác giả nước ngoài khác về vấn đề cho vay tại nông thôn ở Việt Nam.

Nghiên cứu có tiêu đề "Gender differences in formal credit approaches: rural households in Vietnam" trên tạp chí Asian-Pacific Economic Literature (APEL).

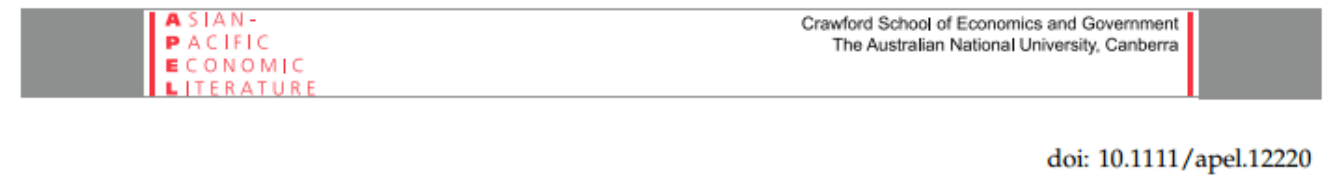

\section{Gender differences in formal credit approaches: rural households in Vietnam}

\section{Thi Kieu Van Tran, $\odot$ Ehsan Elahi, Liqin Zhang, Muhammad Abid, Quang Trung Pham and Thuy Duong Tran*}

Bằng việc phân tích dữ liệu của Vietnam Access to Resources Household Survey (VARHS) các năm 2013-2014 và sử dụng các phân tích logistic và các mô hình hồi quy tuyến tính đa biến và so sánh bằng số đo xu hướng, các tác giả đã chỉ ra một số đặc trưng trong việc cho vay giữa nam và nữ giới tại khu vực nông thôn.

Kết quả phân tích cho thấy, 85\% phụ nữ ở nông thôn sẽ khó vay được so với đàn ông và số tiền những người này vay được cũng có xu hương ít hơn (khoảng 1.8\%) so với số tiền nam giới có thể vay. Các yếu tố như Giới tính, năm đi học, tình trạng hôn nhân, hoạt động nông nghiệp, hoạt động phi nông nghiệp, sở hữu đất nông nghiệp của một người chủ gia đình là nam giới ảnh hưởng tích cực đến sự phân biệt trong 
quá trình cho vay và lượng tiền cho vay. Ngoài ra, các tác giả cũng chỉ ra rằng tính trung bình, nam giới sẽ vay nhiều hơn nữ giới VND 200.000 cho mỗi khoản vay.

Các phân tích trên phù hợp với đặc điểm ảnh hưởng Khổng giáo lâu đời ở Việt Nam, ở hệ thống đó quan hệ nam-nữ vốn được coi là bất cân xứng. Nó cũng cho thấy, mặc dù các quan điểm hiện đại đang tác động lên các thay đổi cấu trúc xã hội cũng như tâm lý gia đình, nhưng hệ thống giá trị cốt lõi văn hóa thay đổi rất chậm.

Tạp chí APEL do nhà xuất bản Wiley ấn hành, có JIF (2016) là 0.455, CiteScore (2016) 0.55 và có H-Index là 16. các mục Economics, Development, Geography, Planning and Development của tạp chí đều xếp hạng Q3 trong năm 2016. Tạp chí được chỉ mục hóa từ năm 1987 đến nay.

\section{References:}

Tran, T., Elahi, E., Zhang, L., Abid, M., Pham, Q., \& Tran, T. (2018). Gender differences in formal credit approaches: Rural households in Vietnam. Asian-Pacific Economic Literature, 32(1), 131-138. doi:10.1111/apel.12220

Vuong, Q. H., \& Tran, T. D. (2009). The cultural dimensions of the Vietnamese private entrepreneurship. IUP Journal of Entrepreneurship Development, VI(3/4): 5478. 